\title{
Poor echocardiographic view can be a sign of the development of thoracic pneumatosis
}

\author{
Keiko Uemura', Mari Ozminsky ${ }^{2}$, Chie Matsuoka ${ }^{2}$ and Satoki Inoue ${ }^{2^{*}}$ (I)
}

\section{To the Editor}

Mechanical ventilation is an essential medical intervention for patients with severe respiratory failure. However, this intervention potentially has a risk of life-threatening adverse events, which include barotrauma or volutrauma that causes air leak into the pleural space resulting in conditions such as pneumothorax, pneumomediastinum and subcutaneous emphysema [1]. Needless to say, pneumothorax, especially tension pneumothorax, is a medical emergency while subcutaneous emphysema is not a severe adverse event. It has been suggested that subcutaneous emphysema may become apparent on chest X-rays before pneumothorax does [2]. Chest X-ray showing subcutaneous emphysema may be used as a sign of progression to thoracic pneumatosis [2]. It would be helpful if there are established signs of subcutaneous emphysema for making a diagnosis in the earlier stages. It is well known that subcutaneous emphysema can reduce the quality of ultrasound images [3]. Recently, we noticed that all patients in our previously reported cases [4-6] had had a poor echocardiographic view before developing severe thoracic pneumatosis during mechanical ventilation. We also reviewed the series of chest X-ray images of these cases before developing severe thoracic pneumatosis and found mild subcutaneous emphysema in those images (Fig. 1). Concurrently with these images, a finding of poor echocardiographic view was recorded in the medical record in each case. From these experiences, it is assumed that we could have prevented the development of life-threatening thoracic pneumatosis if we had

\footnotetext{
*Correspondence: seninoue@fmu.ac.jp

2 Department of Anesthesiology, Fukushima Medical University, 1

Hikarigaoka, Fukushima, Fukushima 960-1295, Japan

Full list of author information is available at the end of the article
}

noticed subcutaneous emphysema in the first poor echocardiographic view. Our cases suggest that we should suspect subcutaneous emphysema in cases with poor echocardiographic view during mechanical ventilation. It is likely that poor echocardiographic view can be considered as a sign of development of thoracic pneumatosis, and we should be aware of this for early prevention.

\begin{abstract}
Acknowledgements
None.

Authors' contributions

$\mathrm{KU}$ and $\mathrm{SI}$ designed the report. $\mathrm{MO}$ and $\mathrm{CM}$ analyzed the data and interpreted the results. MO wrote the first draft of the manuscript. SI revised the manuscript. All authors have read and approved the final version of the manuscript and agreed to submit it.

Funding

This study was supported only by departmental funding from our institution.

Availability of data and materials

Not applicable.

\section{Declarations}

Ethics approval and consent to participate

The institutional review board waived the approval requirement of this report. Informed consent for publication was obtained from each patient.

\section{Competing interests}

The authors declare that they have no competing interests.

\section{Author details}

${ }^{1}$ Department of Anesthesiology, Nara Medical University, 840 Shijocho, Kashihara 634-8521, Japan. ${ }^{2}$ Department of Anesthesiology, Fukushima Medical University, 1 Hikarigaoka, Fukushima, Fukushima 960-1295, Japan.
\end{abstract}

Received: 26 January 2022 Revised: 20 February 2022 Accepted: 22 February 2022

Published online: 27 February 2022

\section{Springer Open}

(c) The Author(s) 2022. Open Access This article is licensed under a Creative Commons Attribution 4.0 International License, which permits use, sharing, adaptation, distribution and reproduction in any medium or format, as long as you give appropriate credit to the original author(s) and the source, provide a link to the Creative Commons licence, and indicate if changes were made. The images or other third party material in this article are included in the article's Creative Commons licence, unless indicated otherwise in a credit line to the material. If material is not included in the article's Creative Commons licence and your intended use is not permitted by statutory regulation or exceeds the permitted use, you will need to obtain permission directly from the copyright holder. To view a copy of this licence, visit http://creativecommons.org/licenses/by/4.0/. 


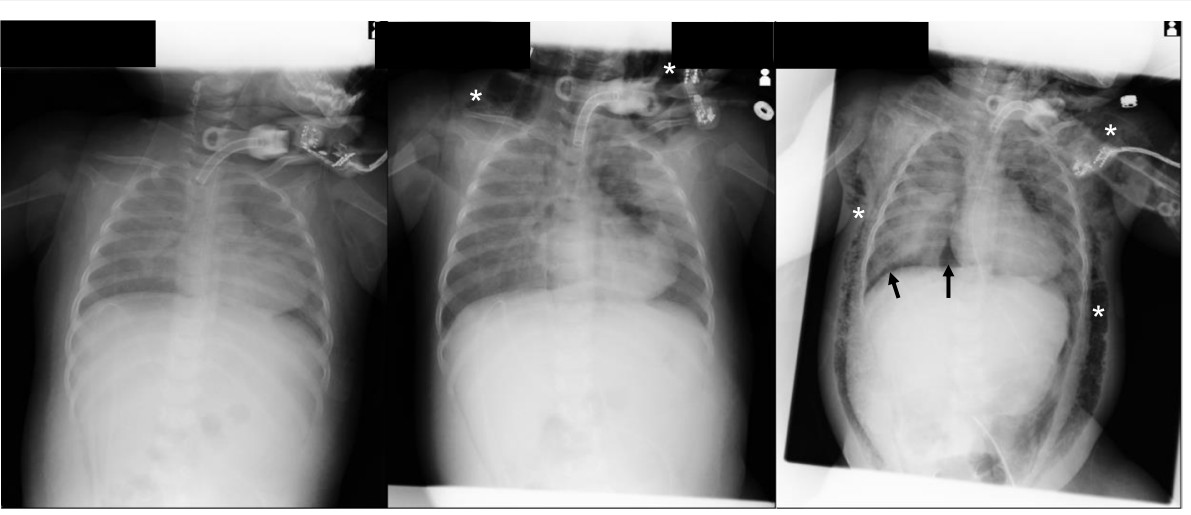

Day X

Day $\mathrm{X}+1$

Day $\mathrm{X}+2$

Fig. 1 Representative $X$-ray images of a patient (an 8-month-old female with weight $5.7 \mathrm{~kg}$ and height $60 \mathrm{~cm}$ ) [5]. On day $X$, good

echocardiographic imaging was obtained; however, the image quality was slightly reduced than the day before. There was no remarkable change suggesting pneumatosis on the $X$-ray image. On day $X+1$, good echocardiographic imaging was not obtained. Taking a closer look at the $X$-ray image, subcutaneous emphysema (asterisks) is observed around the neck. We overlooked this sign because we were distracted by the change of the X-ray image of the left lung field. On day $X+2$, the patient developed severe pneumatosis. The right-side X-ray image shows extensive subcutaneous emphysema (asterisks) and pneumothorax (arrows)

\section{References}

1. Slutsky AS, Ranieri VM. Ventilator-induced lung injury. N Engl J Med. 2013;369:2126-36.

2. Wicky S, Wintermark M, Schnyder P, Capasso P, Denys A. Imaging of blunt chest trauma. Eur Radiol. 2000;10:1524-38.

3. Verniquet A, Kakel R. Subcutaneous emphysema: ultrasound barrier. Can J Anaesth. 2011;58:336-7.

4. Tachiiri Y, Inoue S, Kawaguchi M. A case of thoracic pneumatosis due to severe coughs and tracheal tube displacement induced by tracheal tube size mismatch. JA Clin Rep. 2019;5:8.

5. Ishikawa T, Inoue S, Kawaguchi M. A pediatric case of severe systemic pneumatosis during airway pressure release ventilation. Med Intensiva (Engl Ed). 2020. https://doi.org/10.1016/j.medin.2020.03.013.

6. Inoue S, Nomura Y, Kawaguchi M. Pneumoperitoneum in a patient with Larsen syndrome. J Anesth. 2014;28:478.

\section{Publisher's Note}

Springer Nature remains neutral with regard to jurisdictional claims in published maps and institutional affiliations.

\section{Submit your manuscript to a SpringerOpen ${ }^{\circ}$ journal and benefit from:}

- Convenient online submission

- Rigorous peer review

- Open access: articles freely available online

- High visibility within the field

- Retaining the copyright to your article

Submit your next manuscript at $\boldsymbol{\nabla}$ springeropen.com 